\title{
The elevated risk for venous thrombosis in persons with hyperhomocysteinemia is not reflected by the endogenous thrombin potential
}

Citation for published version (APA):

Bos, G. M. J., Rijkers, D. T. S., Willems, H. P. J., den Heijer, M., Beguin, S., Gerrits, W. B. J., \& Hemker, H. C. (1999). The elevated risk for venous thrombosis in persons with hyperhomocysteinemia is not reflected by the endogenous thrombin potential. Thrombosis and Haemostasis, 81(3), 467-468. https://doi.org/10.1055/s-0037-1614500

Document status and date:

Published: 01/01/1999

DOI:

10.1055/s-0037-1614500

Document Version:

Publisher's PDF, also known as Version of record

Please check the document version of this publication:

- A submitted manuscript is the version of the article upon submission and before peer-review. There can be important differences between the submitted version and the official published version of record.

People interested in the research are advised to contact the author for the final version of the publication, or visit the DOI to the publisher's website.

- The final author version and the galley proof are versions of the publication after peer review.

- The final published version features the final layout of the paper including the volume, issue and page numbers.

Link to publication

\footnotetext{
General rights rights.

- You may freely distribute the URL identifying the publication in the public portal. please follow below link for the End User Agreement:

www.umlib.nl/taverne-license

Take down policy

If you believe that this document breaches copyright please contact us at:

repository@maastrichtuniversity.nl

providing details and we will investigate your claim.
}

Copyright and moral rights for the publications made accessible in the public portal are retained by the authors and/or other copyright owners and it is a condition of accessing publications that users recognise and abide by the legal requirements associated with these

- Users may download and print one copy of any publication from the public portal for the purpose of private study or research.

- You may not further distribute the material or use it for any profit-making activity or commercial gain

If the publication is distributed under the terms of Article 25fa of the Dutch Copyright Act, indicated by the "Taverne" license above, 


\section{References}

1. Miyata T, Sakata T, Zheng YZ, Tsukamoto H, Umeyama H, Uchiyama S, Ikusaka M, Yoshioka A, Imanaka Y, Fujimura H, Kambayashi J, Kato H. Genetic characterization of protein $\mathrm{C}$ deficiency in Japanese subjects using a rapid and nonradioactive method for single-strand conformational polymorphism analysis and a model building. Thromb Haemost 1996; 76: 302-11.

2. Miyata T, Sakata T, Yasumuro Y, Okamura T, Katsumi A, Saito H, Abe T, Shirahata A, Sakai M, Kato H. Genetic analysis of protein C deficiency in nineteen Japanese families: Five recurrent defects can explain half of the deficiencies. Thromb Res 1998; 92: 181-7.
3. Sakata T, Kario K, Katayama Y, Matsuyama T, Kato H, Miyata T. Analysis of 45 episodes of arterial occlusive disease in Japanese patients with congenital protein C deficiency. Thromb Res 1999; in press.

4. Miletich J, Sherman L, Broze G Jr. Absence of thrombosis in subjects with heterozygous protein C deficiency. N Engl J Med 1987; 317: 991-6.

5. Tait RC, Isobel D, Walker ID, Reitsma PH, Islam SIAM, McCall F, Poort SR, Conkie JA, Bertina RM. Prevalence of protein C deficiency in the healthy population. Thromb Haemost 1995; 73: 87-93.

Received August 14, 1998 Accepted after resubmission December 2, 1998

\section{The Elevated Risk for Venous Thrombosis in Persons with Hyperhomocysteinemia Is not Reflected by the Endogenous Thrombin Potential}

Dear Sir,

Several case control studies and a recent prospective study showed that in patients with (idiopathic) venous thrombosis mild hyperhomocysteinemia $(\mathrm{HH})$ can be observed 2-3 times more frequently than in controls (1-3). The pathogenetic explanation for this clinical observation is not known. In principal a thrombotic tendency can originate in the blood, in the vessel wall or at the level of thrombocytes. The question that we wanted to answer was whether the thrombotic tendency that might accompany $\mathrm{HH}$ is caused by a higher capacity of these persons to generate thrombin. The plasmatic component of a thrombotic tendency might be reflected in the capacity of the platelet poor plasma to generate thrombin. This capacity can be assessed by measuring the endogenous thrombin potential (ETP), i.e. the surface under the thrombin generation curve (4-6). It has been shown that the ETP is significantly increased in such plasma based thrombotic tendencies as deficiencies in AT and mutated Factor V Leiden (6,7). The influence of exogenous activated protein $\mathrm{C}$ (APC) $(8,9)$ and exogenous thrombomodulin (TM) $(10,11)$ on the inhibition of the ETP was recently shown and was used to screen for a deficient protein $\mathrm{C}$ pathway. In order to see whether a plasmatic component can explain the thrombotic tendency in $\mathrm{HH}$, we tested the possible relationship between the concentration of homocysteine (tHcy) and thrombin generation in a group of healthy controls, without any venous thrombotic events in the past. Blood samples of 30 persons with elevated levels of tHcy (> $18 \mu$ mol/l; mean: $22.7 \mu \mathrm{mol} / \mathrm{l}$ ) were selected. Samples of 30 persons matched for age and sex with normal tHcy levels (mean: $14.2 \mu \mathrm{mol} / \mathrm{l}$ ) were used as controls (for details on study group selection see ref. 12). Homocysteine values of $>18 \mu \mathrm{mol} / \mathrm{l}$ are clearly associated with increased risk for venous

Correspondence to: Gerard M. J. Bos, Heelblaadjespad 4, 2353 PA Leiderdorp, The Netherlands - Tel.: +31715896466; E-Mail: StouthartBos@wxs.nl

Present addresses: G. M. J. Bos, is presently a fellow of the Dutch Cancer Foundation; D. T. S. Rijkers, Utrecht University, Faculty of Pharmaceutics, Department of Medicinal Chemistry, Utrecht, The Netherlands; M. den Heijer, Department of Internal Medicine, University of Nijmegen, Nijmegen, The Netherlands thrombosis $(13,14)$. We deliberately did not include patients with venous thrombosis in the past, so as to exclude the possibility of plasma changes caused by the thrombotic process itself.

We determined the ETP under standard conditions (extrinsically and intrinsically) and in the presence of exogenous APC or TM. The assay method for determining the ETP is based on the continuous monitoring of thrombin formation using a slow reacting thrombin substrate essentially as described earlier (4) which method has been adapted for high throughput screening on a Cobas centrifugal analyzer (6). The anticoagulant response towards TM was expressed as the thrombomodulin ratio (TMR); TMR: $\left(\mathrm{ETP}_{+\mathrm{TM}} / \mathrm{ETP}_{-\mathrm{TM}}\right)_{\mathrm{pool}} /\left(\mathrm{ETP}_{+\mathrm{TM}} /\right.$ $\left.\mathrm{ETP}_{\text {-TM }}\right)_{\text {sample }}$. The anticoagulant response towards APC was expressed as the APC sensitivity ratio (APC-sr): $\left(\alpha_{2} \mathrm{M}-\mathrm{IIa}_{+\mathrm{APC}} / \alpha_{2} \mathrm{M}-\mathrm{III} \mathrm{a}_{-\mathrm{APC}}\right)_{\text {sample }} /$ $\left(\alpha_{2} \mathrm{M}_{-} \mathrm{IIa}_{+\mathrm{APC}} / \alpha_{2} \mathrm{M}-\mathrm{IIa}_{-\mathrm{APC}}\right)_{\text {pool }}$.

The data on the subjects under study are given in Table 1. There was a narrow association between the intrinsic and extrinsic ETP. The Pearson correlation is $0.876(p=0.001)$ (data not shown). However, for both intrinsic ETP and extrinsic ETP we found no correlation with tHcy. Comparing the two different groups no difference was present between those with normal tHcy levels and those with elevated tHcy levels. The intrinsic ETP in those with elevated tHcy was 412 (99\% of reference plasma) similar to those with normal tHcy. The extrinsic ETP was $100 \%$ of reference plasma in those with eleveated tHcy and $106 \%$ of reference plasma in those with normal tHcy. There was clearly no association between tHcy and TMR (coefficient is $0.04 ; p=0.74$ ) and no difference between the group with high tHcy and those with normal tHcy was observed. Also no difference in APC-sr ratio could be observed between those with high and normal tHcy levels.

Since no association of the ETP and homocysteine levels was observed and no influence of homocysteine on the ETP in the presence of APC or TM, our data do not support the idea that $\mathrm{HH}$ acts via the plasmatic coagulation system. Others suggested a role for factor $\mathrm{V}$ or activated protein $\mathrm{C}$. In addition an enhanced turnover or diminished formation of thrombomodulin has been suggested though not supported by all studies (reviewed in 1 and 15). It should be realized however that most of the observations were made in in vitro systems and that in the in vitro experiments very high levels of (free) homocysteine - up to $10 \mathrm{mmol} / \mathrm{l}$ - were used. These values differ far from the 


\begin{tabular}{llll}
\hline & normal thcy & high thcy & P value \\
thcy (micromol/l) & Mean $=14.2$ & Mean $=22.7$ & \\
tHcy range & $8,4-16,5$ & $18,0-49,8$ & \\
Mean age & $55,2(23-82)$ & $55,1 \quad(23-80)$ & \\
Male (N) & 15 & 15 & \\
Female (N) & 15 & 15 & \\
ETP intrinsic & $412+/-72$ nM.Min & $412+/-66 \mathrm{nM} . \mathrm{min}$ & 0.6 \\
ETP extrinsic & $419+/-65 \mathrm{nM} . \mathrm{min}$ & $395+/-56 \mathrm{nM} . \mathrm{min}$ & 0.15 \\
APC-sr & $1,37+/-0,33$ & $1,41+/-0,51$ & 0,75 \\
TMR & $0,83+/-0,15$ & $0,86+/-0,18$ & 0,37 \\
\hline
\end{tabular}

Table 1 Homocysteine and ETP values of persons under study

Data are presented as mean $+/-1$ SD

statistical analysis After logarithmic transformation of the ETP values,

the APC-sI and the TMR, independent samples T-tests were used to analyse

the differences between the groups with high and low homocysteine. The

SPSS statistical programm was used.

in vivo situation and it is questionable in our opinion whether these in vitro experiments represent the clinical situation. Not finding an association between mild $\mathrm{HH}$ and the ETP renders a direct influence of $\mathrm{HH}$ on plasmatic thrombin generation improbable. Therefore other factors might be relevant such as the fibrinolytic pathway, enhanced tissue factor activity, enhanced platelet aggregation, increased platelet adhesion on endothelial cells, abnormal nitrogen oxides, abnormal endothelium-derived relaxing factor and inhibition of von Willebrand factor production $(1,15)$. Most of the studies supporting these hypotheses are however again limited by the high levels of homocysteine used in the in vitro experiments. It has also been shown that homocysteine might induce altered gene expression in endothelial cells, genes that might possibly be related to the process of thrombosis $(16,17)$.

Until now - to our knowledge - there is however no clear parameter observed in man that might be a clue for the pathogenetic process involved in the association of mild $\mathrm{HH}$ and venous thrombosis. We feel such a parameter is urgently needed to proof that the epidemiological association between $\mathrm{HH}$ and venous thrombosis can more likely be interpreteted as a causative one. Furthermore such a parameter would be very helpful in treatment strategies for HH. Vitamins (folic acid) can easily correct $\mathrm{HH}$ but any antithrombotic effect of any treatment cannot be claimed yet $(12,15,18)$.

\section{Acknowledgements}

This work was supported by a grant from the Dutch Prevention Fund (28-2263-1).

Gerard M. J. Bos, Dirk T. S. Rijkers ${ }^{1}$, Huub P. J. Willems, Martin den Heijer, Suzette Béguin, Wim B. J. Gerrits, H. Coenraad Hemker ${ }^{1}$ From the Dept of Hematology, Leyenburg Hospital, The Hague, and the ${ }^{1}$ Department of Biochemistry and Cardiovascular Research Institute, Faculty of Medicine, Maastricht, The Netherlands

\section{References}

1. D'Angelo A, Selhub J. Homocysteine and thrombotic disease. Blood 1997; 90: 1-11.

2. Ridker PM, Hennekens CH, Selhub J, Miletich JP, Malinow MR, Stampfer MJ. Interrelation of hyperhomocyst(e)inemia, factor V Leiden, and risk of future venous tromboembolism. Circulation 1997; 95: 1777-82.

3. Heijer M den, Rosendaal FR, Blom HJ, Gerrits WBJ, Bos GMJ. Hyperhomocysteinemia and venous thrombosis: a metaanalysis. Thromb Haemost 1998; 80: 824-7.

4. Hemker HC, Wielders S, Kessels H, Béguin S. Continous registration of thrombin generation in plasma, its use for the determination of the thrombin potential. Thromb Haemost 1993; 70 (4): 617-24.
5. Hemker HC, Béguin S. Thrombin generation in plasma: Its assessment via the endogenous thrombin potential. Thromb Haemost 1995; 74 (1): 134-8.

6. Wielders S, Mukheerje M, Michiels J, Rijkers DTS, Cambus J-P, Knebel RWC, Kakkar V, Hemker HC, Béguin S. The routine determination of the endogenous thrombin potential, first results in different forms of hyperand hypocoagulability. Thromb Haemost 1997; 77: 629-36.

7. Rotteveel RC, Roozendaal KJ, Eijsman L, Hemker HC. The influence of oral contraceptives on the time-integral of thrombin generation (thrombin potential). Thromb Haemost 1993; 70 (6): 959-62.

8. Nicolaes GAF, Thomassen MCLGD, van Oerle R, Hamulyak K, Hemker HC, Tans G, Rosing J. A prothrombinase-based assay for detection of resistance to activated protein C. Thromb Haemost 1996; 76: 404-10.

9. Nicolaes GAF, Thomassen MCLGD, Tans G, Rosing J, Hemker HC. Effect of activated protein $\mathrm{C}$ on thrombin generation and on the thrombin potential in plasma of normal and APC-resistant individuals. Blood Coag Fibrinol 1997; 8: 28-38.

10. Duchemin J, Pittet JL, Tortary M, Béguin S, Gaussem P, Alhenc-Gelas M, Aiach M. A new method based on thrombin generation inhibition to detect both protein $\mathrm{C}$ and Protein $\mathrm{S}$ deficiencies in plasma. Thromb Haemost 1994; 71: 31-338.

11. Rijkers DTS, Wielders SJH, Alhenc-Gelas M, Béguin S, Hemker HC. The thrombomodulin ratio: a screening test for the protein $\mathrm{C}$ pathway. Thromb Haemost 1997; 77 (Suppl): 2251 (Abstract).

12. Heijer M den, IA Brouwer, GMJ Bos, HJ Blom, AP Spaans, FR Rosendaal, Thomas CMG, Haak HL, Weijermans PW, Gerrits WBJ. Vitamin supplementation reduces blood homocysteine levels: a controlled trial in patients with venous thrombosis and healthy volunteers. Arterioscler Thromb Vasc Biol 1998;18: 356-61.

13. Heijer M den, Blom HJ, Gerrits WBJ, Rosendaal FR, Haak HL, Wijermans $\mathrm{PW}, \mathrm{Bos}$ GMJ. Is hyperhomocysteinaemia a risk factor for recurrent venous trombosis? Lancet 1995; 345: 882-5.

14. Heijer M den, Koster T, Blom HJ, Bos GMJ, Briët E, Reitsma PH, Vandenbroucke JP, Rosendaal F. Hyperhomocysteinemia as a risk factor for deep-vein thrombosis. NEJM 1996; 334: 759-62.

15. Welch GN, Loscalzo J. Mechanisms of disease: Homocysteine and atherothrombosis. NEJM 1988; 338 (15): 1042-50.

16. Tsai J, Wang H, Perrella MA, Yoshizumi M, Sibinga NES, Tan LC, Haber E, Hung-Tse Chang T, Schlegel R, Lee M. Induction of cyclin a gene expression by homocysteine in vascular smooth muscle cells. J Clin Invest 1996; 97: 146-53.

17. Kokame K, Kato H, Miyata T. Homocysteine-respondent genes in vascular endothelial cells identified by differential display analysis. J Biol Chem 1996; 271 (47): 29659-65.

18. Homocysteine Lowering Trialist Collaboration. Lowering blood homocysteine with folic acid based supplements: meta-analysis of randomised trials. BMJ 1998; 316: 894-8.

Received July 31, 1998 Accepted after resubmission December 1, 1998 